\title{
Wilfried HACKENBROICH
}

\section{Prehodni prostor: Koridor Berlin-Moskva in nemško-poljska meja do Poznana}

$\checkmark$ prispevku je govor o infrastrukturnih raziskavah povezanih s prostorskim redom koridorja Berlin-Moskva in njegovim najdinamičnejšim delom, ki leži med nemško-poljsko mejo in Poznanom. Zasnovan je na raziskavi, ki so jo opravili v sklopu Bauhaus Kolleg V, Tranzitni prostori: tranzicijska mesta $v$ vzhodni Evropi, v letih 2003/2004 na skladu Bauhaus Dessau. Koridor med Berlinom in Moskvo je primer novega prostorskega reda $v$ postsocialistični Evropi, pretoka kapitala in dobrin, migracijskih tokov, širitve EU, komunikacijskih omrežij, ki jih skupaj drži infrastruktura. Tranzicijska gospodarstva in večplastne alokacijske politike so proizvod premika EU proti vzhodu in obenem povzročajo nove prostorske strukture in razlikovanja. Nove nevidne, toda učinkovite prostorske ovire in obrobja nadomeščajo državne meje. Raziskani primeri ob dvopasovni tranzitni cesti med nemško-poljsko mejo in Poznanom odkrivajo intenzivno verigo servisnih postaj, 24-urnih barov, nočnih klubov, restavracij in hotelov. Ob novoodkriti prometni osi so kompleksne servisne postaje umestili in zgradili $v$ doslej nerazvitem prostoru - kot nanizane bisere. To so vozlišča v omrežju globalnega pretoka dobrin, informacij in proizvodov vsakodnevne rabe. Prispevek raziskuje razmere in priložnosti tega območja v sklopu razvoja Evrope.

\section{Prehodni prostor}

Program Tranzitni prostori: tranzicijska mesta v vzhodni Evropi 2003/04 obravnava dinamiko urbanih transformacijskih procesov v vzhodni Evropi. To je podiplomski, mednarodni in interdisciplinarni program sklada Bauhaus Dessau, ki ga je zasnovala Regina Bittner.

V projektu Prehodni prostori Bauhaus Kollega so predmet raziskovanja in scenarijev
Transit space is about the infrastructure investigations concerning the spatial order of the "corridor " Berlin - Moscow and the most dynamic part of the "corridor "from the German-Polish Border to Poznan. It is based on the research conducted during the Bauhaus Kolleg V, "Transit Spaces: Transitional Cities in Eastern Europe « 2003/04 in the Bauhaus Dessau Foundation. The corridor between Berlin and Moscow is one example for a new spatial order within the postsocialism of Eastern Europe, and the flow of capital and goods, migrant streams, the EU expansion, communication networks and the development of the infrastructure holding it together. Transit economies and multilayered new allocation policies result from the shifting of the EU to the East, and cause new spatial structures and differentiations. Beyond the national borders, new invisible but effective spatial barriers and frontiers have emerged. The case studies, along the two lane transit road from the German Polish border to Poznan reveal an intense sequence of service stations, 24 hour bars, night clubs, restaurants and hotels. Complex service stations were built and placed - like pearls on a chain - along new goods traffic axes at so far undeveloped territories. They are nodes in the network of a global flow of goods, information and products of daily use. This article investigates the conditions and prospects of this new area within the European development.

transformacije urbanega. Osemindvajset udeležencev iz šestnajstih držav je raziskovalo primere sedmih lokacij (pojavov) ležečih v koridorju: mejni prostor med Nemčijo in Poljsko, mejno mesto Brest (svetovalec Wilfried Hackenbroich, arhitekt), mestno javno sfero v Minsku, mikroobmočja v Smolensku (svetovalec Kai Vöckler, umetnik), »clubbing « v Varšavi, trgovanje v kioskih Smolenska in globalno nogometno kulturo v Moskvi (svetovalka Regina Bittner, raziskovalka kulture).
Postsocialistični razvoj infrastrukture Prehodni koridor Berlin-Moskva Procesi sprememb Storitvene aglomeracije $v$ mejnem prostoru Tranzicijska mesta Vzhodna Evropa

Border space service agglomeration Eastern Europe Post socialism infrastructure development Transformation processes Transit corridor Berlin-Moscow Transitional Cities 
$\mathrm{V}$ tem prispevku je poudarek na raziskavah infrastrukture, ki vplivajo na prostorski red koridorja Berlin-Moskva oziroma na njegov najdinamičnejši del med nemško-poljsko mejo in mestom Poznan.

Prehodni prostor je metafora za kompleksno družbeno in prostorsko dinamiko, ki sovpada s padcem železne zavese. Sočasnost družbenih transformacij in globalnih strukturnih sprememb, ki se odvijajo v državah nekda-

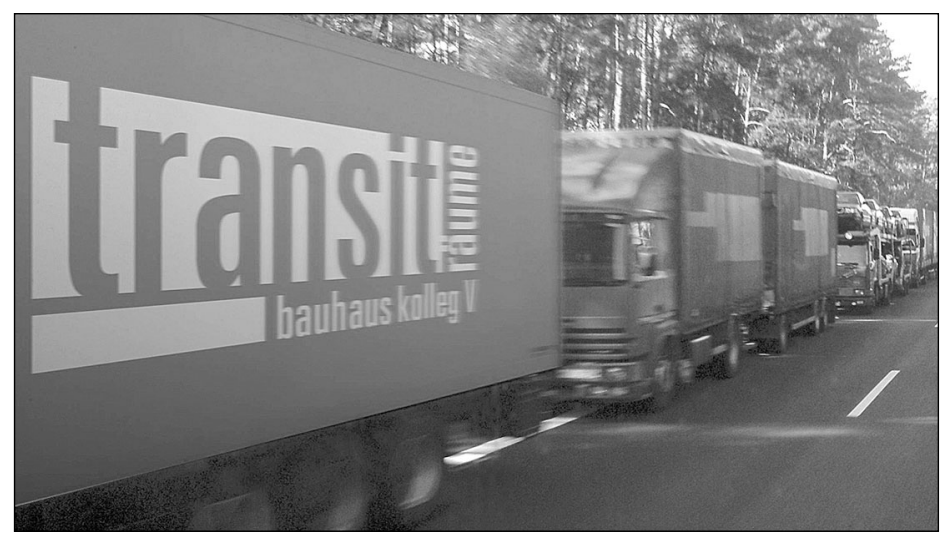

Slika 1: Transitspace, Bauhaus Dessau Foundation, Kolleg V. (Foto: Leonardo Finotti, montage: Rainer Mühr)

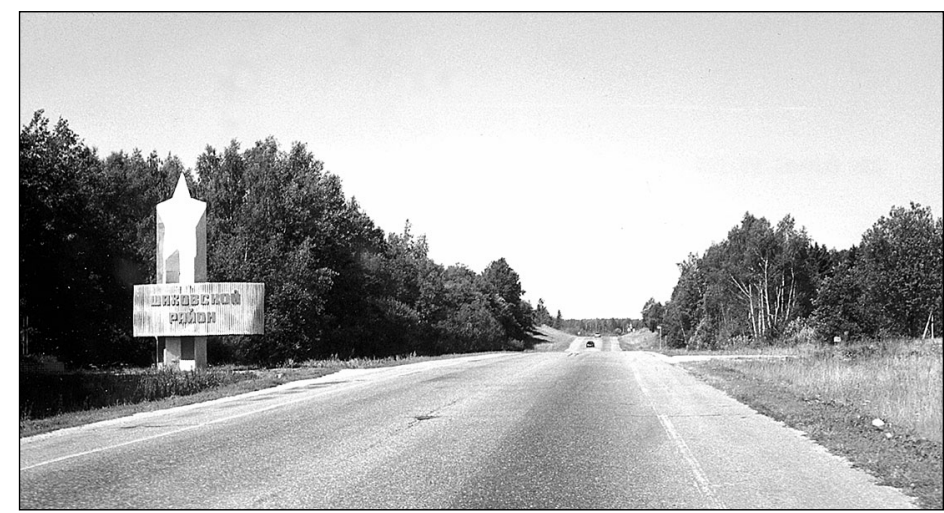

Slika 2: Tranzitni koridor Berlin-Moskva, ruski del. (Foto: Kai Vöckler)

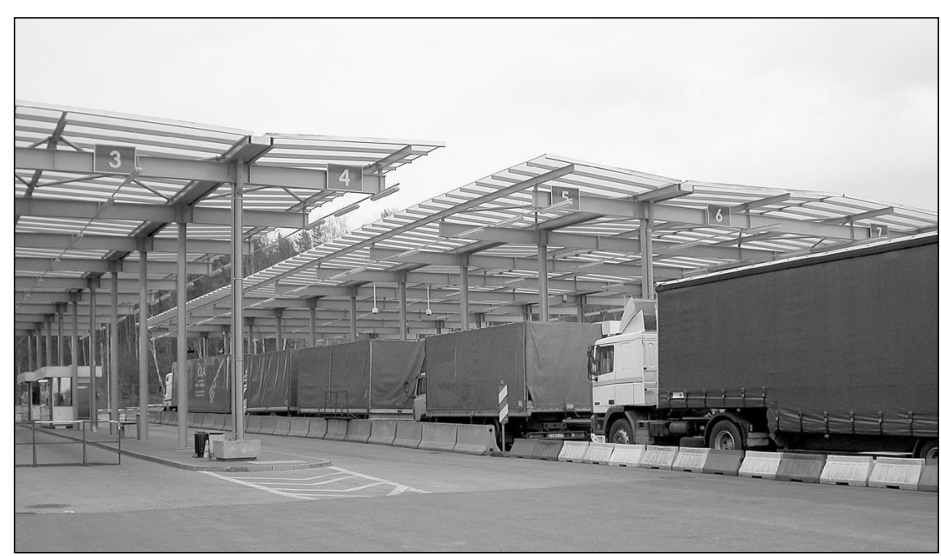

Slika 3: Nemško-poljska meja, nadzor tovornjakov. (Foto: Leonardo Finotti) njega vzhodnega bloka, prinaša korenite transformacije v urbanih prostorih. Koridor med Berlinom in Moskvo je en primer novega prostorskega reda $\mathrm{v}$ postsocialistični vzhodni Evropi. Skupaj ga držijo pretok kapitala in dobrin, pretok migrantov, širitev EU, komunikacijskih omrežij in razvoj infrastrukture. »Post « v izrazu postsocializem se ne nanaša na preteklost, temveč na novo prostorsko omejitev: postindustrijske prostorske aglomeracije in srednjeveško kmetijstvo, zamejene skupnosti in razpadajoče mikrocone ali trgovine Escade in spomeniki Leninu.

\section{Opis koridorja}

Koridor med Berlinom in Moskvo je že več kot tristo let eno najobčutljivejših geostrateških območij Evrope. Simbolizira mnogo uničujočih vojn več diktatorjev, razdelil je generacije, toda hkrati je ena najpomembnejših kulturnih in trgovskih osi. Preseganje blokovskih delitev, meja in zidov se je zgodilo $\mathrm{v}$ času, ko se ta prostor, ki ga je večina prebivalcev stoletja občutila kot nepremagljivega, danes navidezno odpira udobnemu tranzitu.

Že od zgodnjih 90. let prejšnjega stoletja je koridor pod vplivom nove hierarhije in prostorskih neenakosti. Vera $\mathrm{v}$ paradiž na drugem koncu ceste, z obeti zaposlitve, bogastva, neskončnih možnosti in socialne varnosti za vse, se je kmalu razblinila. Kompleksni dejavniki, kot so oskrbna infrastruktura, državna in evropska delovna migracija, stroge politike in pogoji EU v zvezi s strukturno podporo, so pripeljali do novih - do takrat pretežno nevidnih - prostorskih omejitev. Prehodna gospodarstva in nove večplastne lokacijske politike so proizvod širitve EU proti vzhodu in hkrati povzročajo nove prostorske strukture in razlikovanja. Nad državnimi mejami so nastale nove, sicer nevidne, vendar učinkovite prostorske ovire in obrobja.

Raziskali smo tranzitni prostor ob metropolitanskem koridorju od Berlina do Moskve. Ta koridor omogoča izmenjavo dobrin med trgi vzhodne in zahodne Evrope - konvoji tovornjakov se valijo po tranzitnih poteh - poleg tega pa so v njem železniške povezave, omrežja mobilne telefonije in medmrežne vezi. Sestavlja ga veriga privilegiranih lokacij postavljenih na osnovo industrijskega območja, v katerem je mogoče prepoznati vse znanilce socialistične modernizacije in doži- 
veti naraščajoče razpadanje povzročeno s transformacijami ter globalnimi strukturnimi spremembami. Prehodni prostori so stičišča v katerih se podeželske skupnosti srečujejo s svetom Nike, Nokie in CNN. To so nove urbane lokacije, v katerih so eksplozivni potenciali, lastni skupni umestitvi novih vzhodnoevropskih neenakosti in pomanjkanja sočasnosti, hudo očitni.

V naših raziskovanjih smo zelo kmalu ugotovili, da je koridor mentalna tvorba. Raznovrstnost fizičnih razmer v prehodnem prostoru popolnoma sovpada s političnimi, družbenimi in kulturnimi razmerami. Vseh 2.500 $\mathrm{km}$ koridorja je razdrobljenih in različnih. Z risanjem različnih kart smo odkrili silnice posameznih delov. Med njimi so inventarizacije storitev in infrastrukture, podatki, ki smo jih zbrali med potovanjem iz Berlina $\mathrm{v}$ Moskvo, karte iz tiskanih virov, npr. cestnega omrežja, mobilne telefonije, zračnih poti in političnih zvez, npr. EU, OVSE, COMECON in Varšavskega pakta, pa tudi »mentalne« mape prek iskanja podob v Googlu, ki kakovostno in številčno opredelijo, kakšno vidno prepoznavnost imajo mesta in države $\mathrm{v}$ mednarodni medmrežni skupnosti. Te karte, skupaj s poročili, intervjuji in videofilmi, so nam dale globlje vedenje o mehanizmih in razvoju med Berlinom in Moskvo.

\section{Razmere $\mathrm{v}$ koridorju}

Šestintrideset ur: toliko traja potovanje z avtobusom iz Berlina v Moskvo. Dremanje potnikov prekinjajo kratki postanki na široki in različno razviti cesti ter mejnih nadzornih točkah. Bližje so domu, bolj se delovne in življenjske izkušnje zahodne Evrope razblinjajo, spreminjajo v nič. Potujejo prek novih prednostnih prostorov, skozi mesta, kjer se je čas ustavil. Rusi zaposleni v Berlinu v donosnih poklicih lahko priletijo v Moskvo v nekaj urah. Potovanje v isti smeri z avtobusom je poceni, vendar edina možnost za mnoge.

Če odmislimo tranzicijo, so v koridorju zelo različne fizične razmere, hkrati tudi reže heterogene politične in gospodarske okoliščine. Prostor med Berlinom in nemško-poljsko mejo je zelo razvit, zgradili so novo infrastrukturo, nekdanji politični in ekonomski sistem NDR so prilagodili zahodnonemškemu vzoru. Od leta 1991 so vložili skoraj 35 milijard EUR v 17 infrastrukturnih projektov in skoraj $550 \mathrm{~km}$ avtocest visokega standarda.[1] Da bi pospešili ekonomski razvoj vzhodnega dela združene Nemčije, so zahtevali še več. Leta 2004 se je v Nemčiji razvila politična razprava o pravilnosti teh naložb. Če pogledamo ta šestdesetkilometrski odsek, kmalu ugotovimo, da je tukaj najboljša infrastruktura $\mathrm{v}$ koridorju, toda vpogled $\mathrm{v}$ gospodarske razmere pokaže, da je ta del Nemčije v bistvenem zaostanku za zahodom: mesta zgubljajo prebivalstvo, stopnja nezaposlenosti je izjemno visoka, povprečni dohodek je pod državnim povprečjem. Toda v primerjavi z vzhodnim delom ima nemški del koridorja najvišji življenjski standard (socialna varnost, socialna blaginja, izobraževanje), vendar je še daleč od dinamične rasti ali pozitivnega razvoja.

Meja med Nemčijo in Poljsko je v tranziciji. Med našo raziskavo v letih 2003-2004 je že razpadala. Maja 2004 so umaknili carinske mitnice, saj je Poljska takrat postala polnopravna članica EU. Ohranili so imigracijski nadzor, tega bodo odpravili leta 2008. Meja

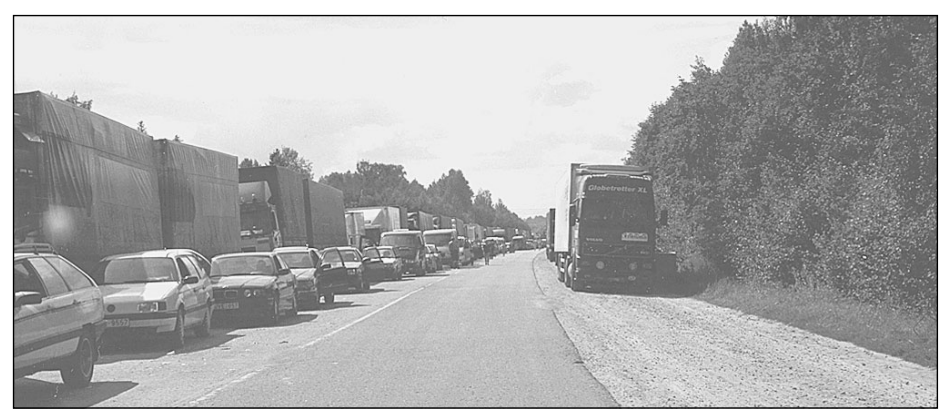

Slika 4: Na poljski strani nemško-poljske meje je vrsta čakajočih tovornjakov lahko dolga 30 kilometrov, čakalna doba pa daljša od 30 ur. (Nina Gribat)

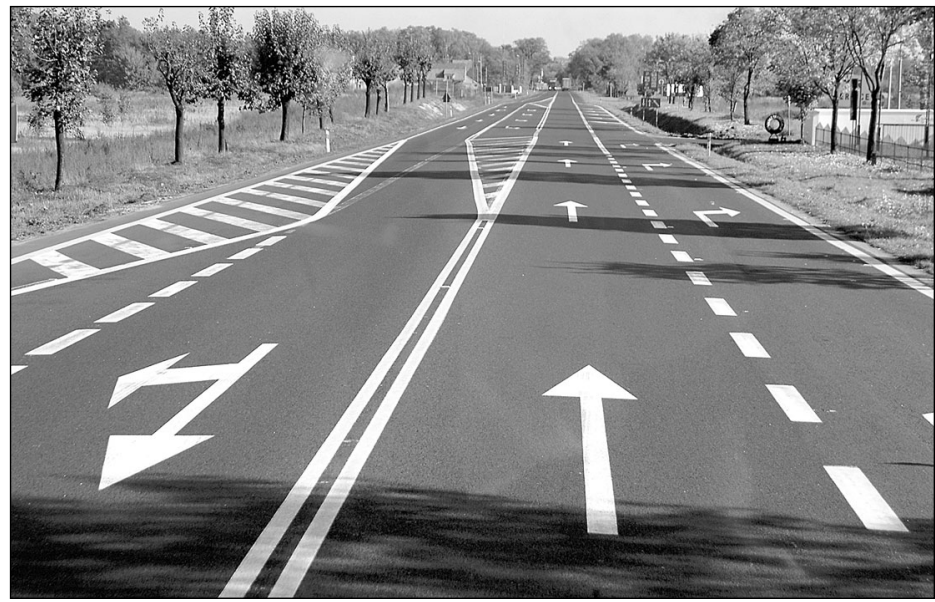

Slika 5: Tranzitni koridor od nemško-poljske meje do Poznana (Foto: Leonardo Finotti) 


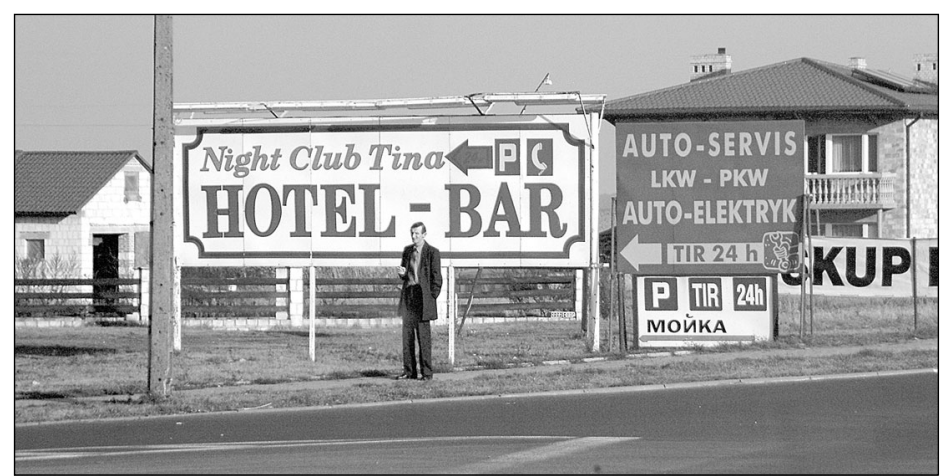

Slika 6: Oznake servisov ob E30 na Poljskem. (Foto: Leonardo Finotti)

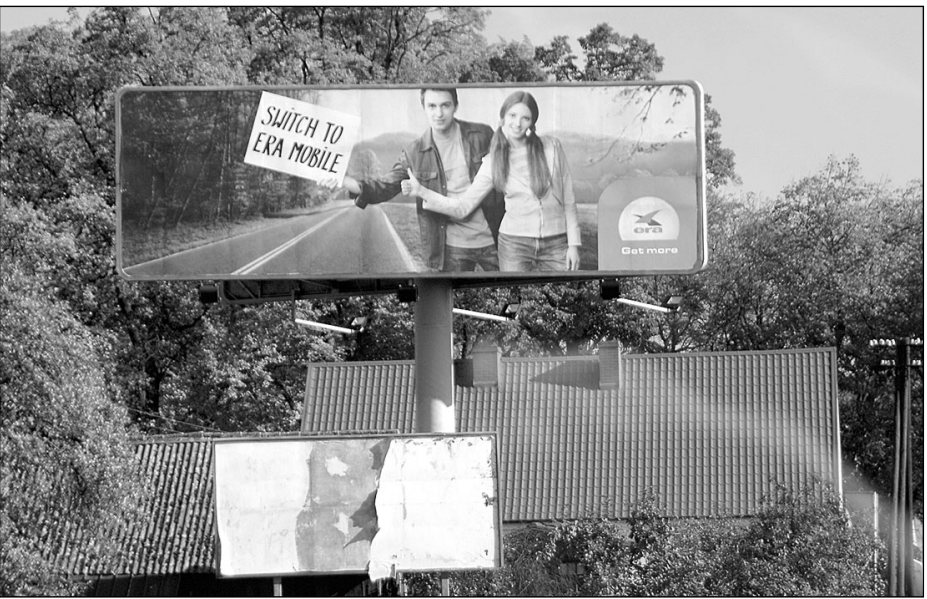

Slika 7: Servisni billboard operaterja mobilne telefonije ob E30 na Poljskem. (Foto: Leonardo Finotti)

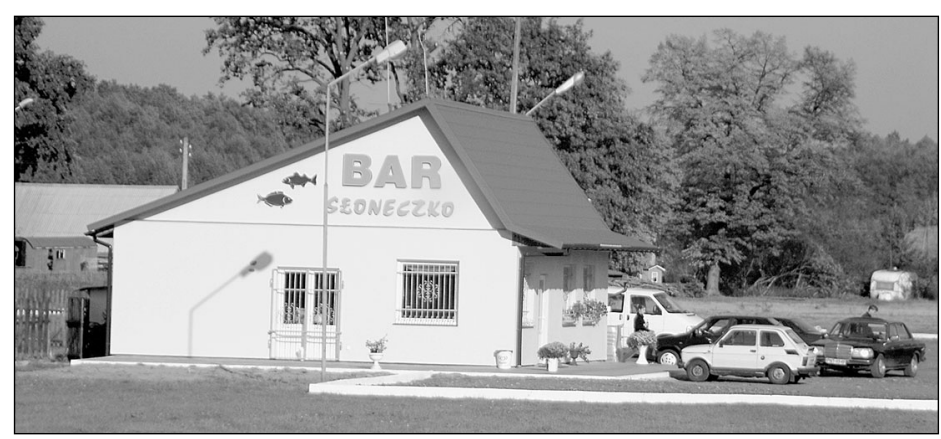

Slika 8: Mono-funkcionalna enota ob E30 na Poljskem. (Foto: Leonardo Finotti)

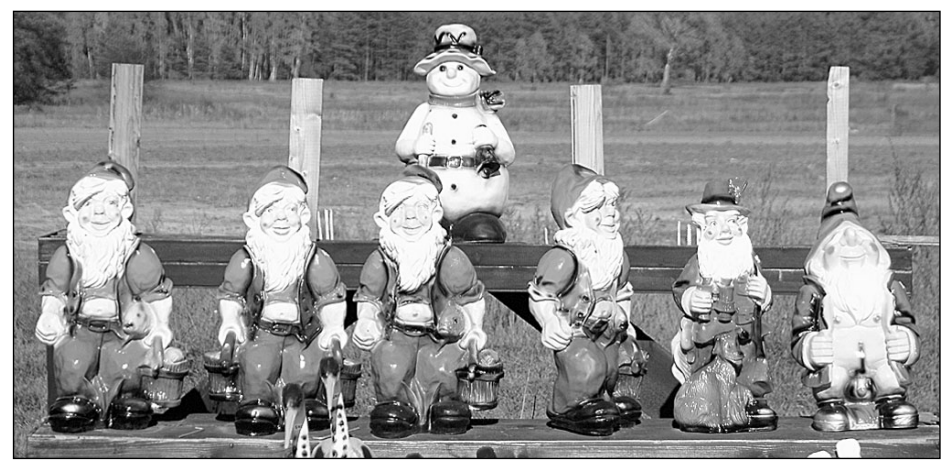

Slika 9: Neformalna prodaja ob E30 na Poljskem. (Foto: Leonardo Finotti) je bila nekoč odprta, saj sta bili obe državi članici istega političnega bloka (COMECON, Varšavski pakt do leta 1991). V zadnjih trinajstih letih je delila dva svetova, bila je zamašek za migracije, formalno in neformalno trgovanje, varnostna črta EU in prostor, kjer so prevozniki čakali tudi 30 ur na prehod. Med letoma 1991 in 2000 so v skladu z evropskimi standardi nadzorne točke razširili in prenovili, leta 2008, z odpravo nadzora potnih listov, bo meja povsem izginila.

Meja je vseeno na Poljskem v zahodnem delu koridorja spodbudila neverjeten razvoj. Zaradi bližine in dostopnosti EU se je v okolici Poznana in Varšave začel hitri razvoj. Tamkajšnja industrija je izkoristila razliko med EU in Poljsko. Zlasti nižje plače in poljski proizvodni standardi, pa tudi bližina potrošnikov v EU so povečali obseg mednarodnih naložb. Varšava je pritegnila mednarodne storitve (bančništvo, glavne pisarne, upravo idr.), območje okoli Poznana pa proizvodnjo, zasnovano na tradiciji trgovinskega sejma in različnih industrijskih obratih. Takšen gospodarski razvoj je sprožil verižno reakcijo ob koridorju, bistveno več prometa se premika po cesti med Berlinom in Poznanom, tako da se to majhno podeželsko cesto zdaj uporablja za globalni pretok dobrin. Posledično so ustanovili majhna, neformalna podjetja, ki strežejo potrebam mobilnosti, najprej z neformalnim razvojem, v zadnjem času bolj formalnim, kjer prevladujejo globalni ponudniki storitev. Še vedno uporabljajo staro podeželsko cesto, medtem ko počasi gradijo novo avtocesto.

V vzhodni Poljski koridor tako rekoč izgine, cesta je ozka, storitve so minimalne. Vzhodna Poljska je tradicionalno deprivilegirano območje, na katerem še danes prevladujejo kmetijstvo, opuščeni industrijski obrati, šibka gospodarska rast in visoka stopnja nezaposlenosti. Na tem območju smo raziskali Siemiatycze, majhno vas s 15.000 prebivalci.[2] Četrtina prebivalcev je zaposlena $\mathrm{v}$ tujini na delih, ki jih drugi Evropejci ne marajo; večina dela v Bruslju, v Belgiji, tja potujejo z avtobusi. Delovna mobilnost je na Poljskem pogosta in ustvarja dodatni promet na koridorju $\mathrm{k}$ zahodu.

Na poti med Poljsko in Belorusijo se na koridorju dejavnosti nenadoma zgostijo v Terespolu pred mejo, kjer se potnik znajde $\mathrm{v}$ vrsti čakajočih pred prehodom. Ta meja je doživela podobne spremembe kot tista med Nemči- 
jo in Poljsko; do leta 1991 je bila mehka meja med »bratskima« državama. S takratno uveljavitvijo Skupnosti neodvisnih držav (SND) je postala razdelitvena črta med državami pod ruskim nadzorom in kandidatkami za članstvo v Natu (Poljska je postala članica leta 1999). Leta 2004 s članstvom Poljske v EU je meja »otrdela«, saj je postala meja med EU in SND. V prihodnosti bo režim še trši, do leta 2008 EU načrtuje obsežen razvoj nadzora: opazovalni stolpi bodo zgrajeni na vsakih $15-20 \mathrm{~km}$ te $1.143 \mathrm{~km}$ dolge meje, zračno opazovanje bo izvajano s petih postaj, na razpolago bo 60 mobilnih ročnih nadzornih naprav, postavili bodo 236 toplotnoobčutljivih kamer in število 5.300 mejnih stražarjev več kot podvojili.[3] Toda hkrati se dogajajo različni preboji meje. $S$ pobudami INTEREG [4], PHARE CBC [5] in Tacis CBC [6] jih spodbuja EU, namenjene pa so podpori razvoja infrastrukture v sosednjih državah.

$\mathrm{V}$ mestu Brest se zavedajo nove dolžnosti »varovanja Evrope pred neželenimi elementi « [7] toda razvili so t. i. program TRIC (orig. Transborder Information and Contact platform), ki je del EU-programa Tacis za spodbujanje izmenjave med regijama Bresta in Bialo Podlasko na Poljskem. Prihajajoči »sosedski program ${ }^{[8]}$ EU bo omo-

gočil boljšo koordinacijo čezmejnega sodelovanja in povečal blaginjo ter stabilnost na obeh straneh meje, tako da bo državam, ki niso članice EU, omogočeno sodelovanje v gospodarskem razvoju brez nujnih političnih posledic, ki jih članstvo zahteva. Poleg omenjenega preboja EU je v Brestu še eden, in sicer Prosta gospodarska cona na dveh proizvodnih območij, ki sta eksteritorialni. Carinjenje držav uvoznic se izvaja neposredno v tej coni, davki so nižji, proizvodni standardi in plače pa nižji kot v EU. Še več, preboji

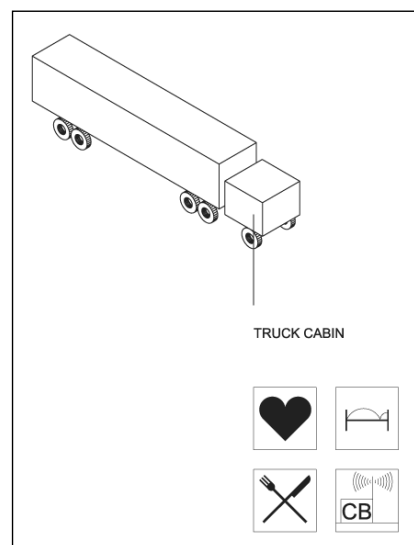

Slika 10: Tovornjak je mobilna tipologija $\vee$ koridorju. (Nina Gribat in Linda Hilfling)

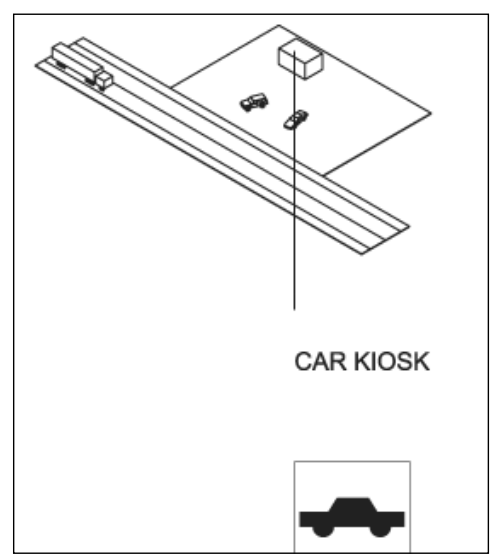

Slika 11: Mono-funkcionalna enota je osnovna tipologija servisov. (Nina Gribat in Linda Hilfling)

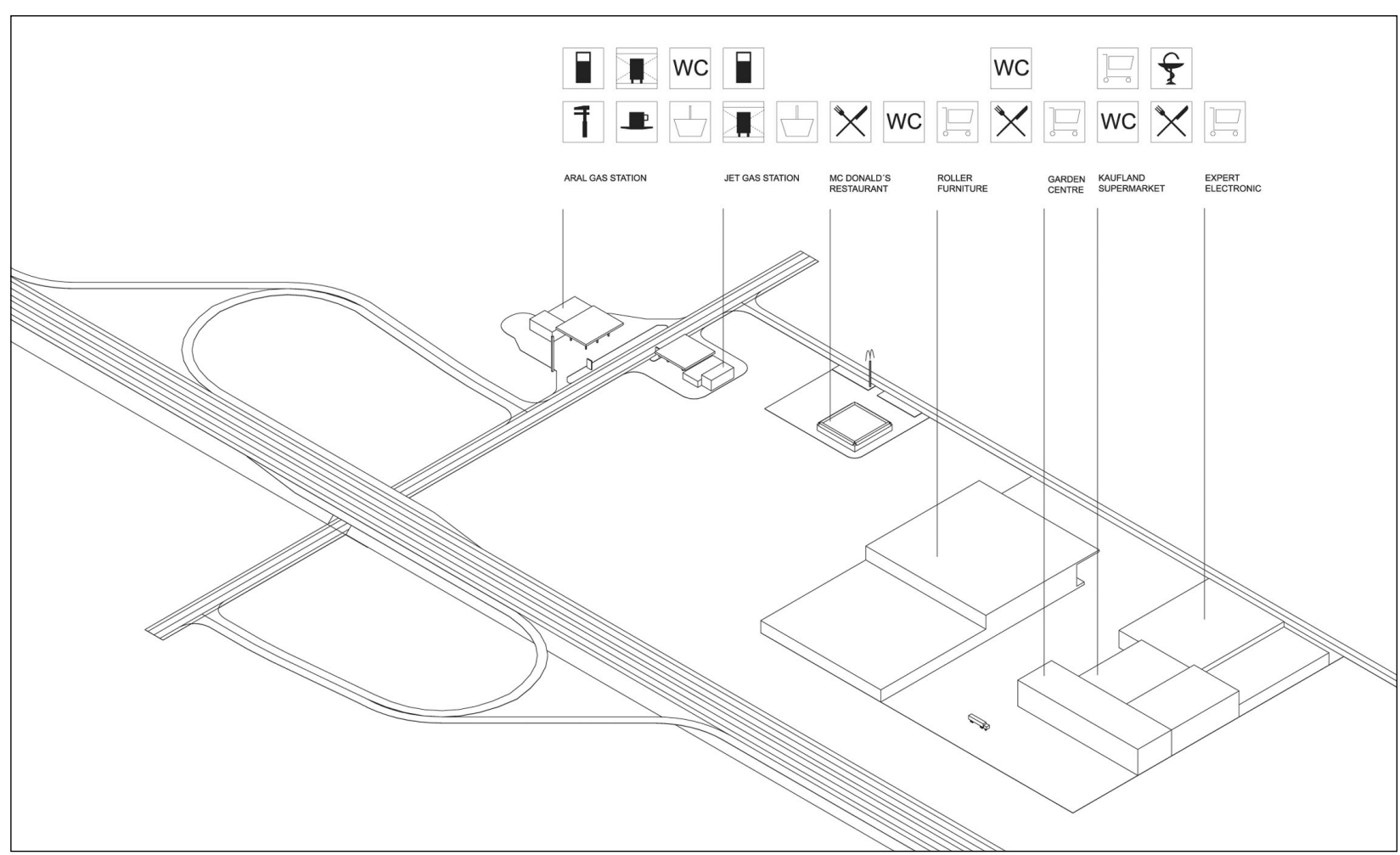

Slika 12: Avtocestni multi-kompleks je značilna, lokalna nepovezana servisna aglomeracija ob nemških avtocestah. (Nina Gribat in Linda Hilfling) 
meje so spodbudili lokalno gospodarsko srenjo k dejavni neformalni ekonomiji. Priložnostni trgovci, večinoma nekdanji menedžerji, učitelji ali inženirji, prečijo poljskobelorusko mejo in na Poljskem trgujejo z belorusko vodko in cigareti, v Brestu pa proda-

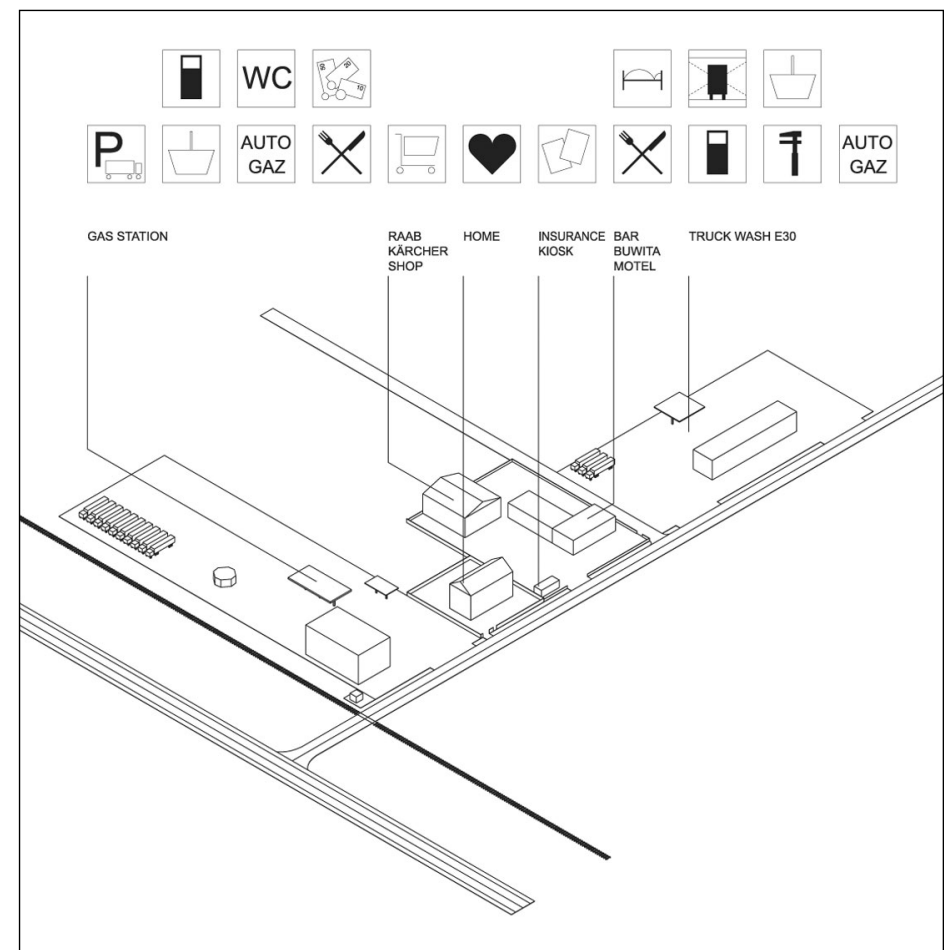

Slika 13: Samonikla servisna aglomeracija z bencinsko črpalko, restavracijo, barom, pralnico in servisom za tovornjake in prostitucijo. (Nina Gribat in Linda Hilfling)

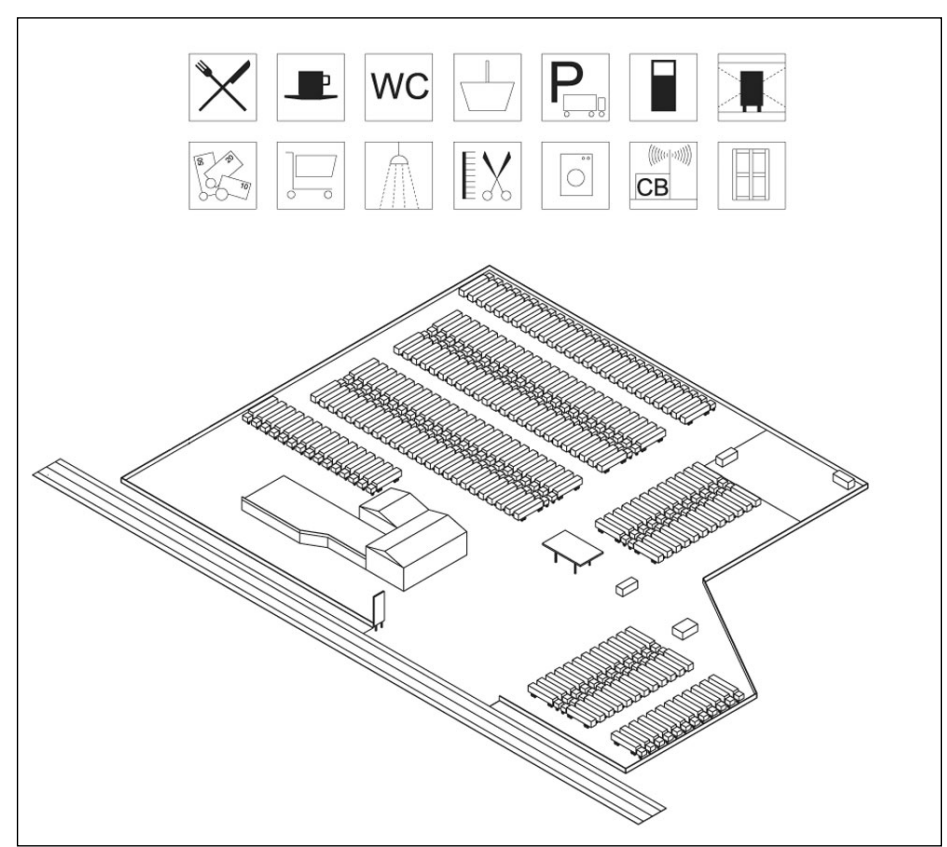

Slika 14: Servisna enota tipa »vse v enem « je nova tipologija, ki spremeni samoniklo strukturo $v$ načrtovani sistem. (Nina Gribat in Linda Hilfling) jajo cenejše poljske izdelke. Takšno »mravljinčasto « trgovino neposredno ogrožajo spremenjeni predpisi o vizumih, a se jim ti neformalni trgovci vedno sproti prilagodijo.

Obmejno mesto Brest najbolj nazorno kaže učinke velikopoteznega političnega in gospodarskega razvoja. Na tranzitnem koridorju skozi Belorusijo te spremembe niso tako očitne, saj gre za štiripasovno avtocesto, ki teče mimo redkih vasic. Ob avtocesti je manj počivališč, navadno so bolj formalna in združena $z$ bencinskimi servisi. Nove sestavine ob cesti so nadzorne policijske postaje in spomeniki, pomniki mnogo bojev iz različnih vojn v minulih stoletjih. V nasprotju s Poljsko je tukaj tranzitni koridor bolje organiziran in nadzorovan, ampak tudi bistveno manj $\mathrm{v}$ rabi lokalnega gospodarstva. Ob cesti so tu in tam kvečjemu prodajalci sadja in zelenjave.

Meja med Belorusijo in Rusijo ni prav trda. Državi sta članici političnega in gospodarskega zavezništva (SND) in si delita predpise, pristojnosti o vizumih in carinskem nadzoru. Nadzor na meji se vsekakor izvaja, toda čakalni čas je kratek, nadzor pa površen. Za mejo, na ruski strani, se količina neformalnih storitev, servisnih aglomeracij, spomenikov in velikih oglasnih panojev (billboardov) poveča, infrastruktura pa poslabša, saj je cesta pretežno dvopasovna. S približevanjem Moskvi se obseg prometa veča, sledi mu več servisov, bencinskih črpalk in billboardov. Na obrobju Moskve je vrhunec, kjer billboardi že povsem zakrivajo večnadstropne stanovanjske stavbe.

\section{Opis E30 od nemške meje do Poznana}

V poglobljeni raziskavi smo se posvetili 200 km tranzitnega koridorja od nemško-poljske meje do Poznana. Analizirali smo prostorsko organizacijo, arhitekturno tipologijo in storitve v vozliščih omrežja. Raziskali smo razvojne posege in regije ob koridorju in igralce $\mathrm{v}$ tem obmejnem prostoru.

Ob dvopasovni tranzitni cesti med mejo in Poznanom se razpira intenziven odsek servisnih postaj, 24-urnih barov, nočnih klubov, restavracij in hotelov. Kompleksne servisne postaje so umestili in zgradili kot bisere na ogrlici - ob novi prometnici za dobrine v do 
zdaj nerazvitem prostoru. To so vozlišča na omrežju globalnih tokov dobrin, informacij in proizvodov za vsakodnevno rabo. Povečani promet, ki ga pospešuje izmenjava med vzhodno Evropo in EU, je učinkoval na ta prehodni prostor. Transformacija nekdanje podeželske ceste $\mathrm{v}$ tranzitno nazorno kaže prostorski vpliv sprememb mejnih predpisov, gospodarskih dejavnikov, različnih dohodkov in pretoka dobrin. Meja med EU in vzhodno Evropo se je spremenila v mejni prostor, 200 km dolgi krak, ki seže v Poljsko. Vsa regija se je prilagodila potrebam mednarodnega tranzita, tako da lahko sodeluje $\mathrm{v}$ pretoku dobrin in kapitala.

Gruče ali točke servisov rastejo iz drobnega merila vaških struktur in sledijo novim pravilom. Te servisne postaje so rastoče pravilo, ki daje nove obrise lokalnemu prostoru. Takšni novi prostori najprej dajejo prve spodbude celotnim regijam, potem pa postanejo prednostni prostori za vmesnike z omrežji. Nova omrežja ustvarjajo globalni igralci, hranijo, vodijo in usmerjajo pa jih iz teh servisnih postaj. Prekrivajo se s starimi omrežji. Nova geografija nastaja, od stare se razlikuje prav v servisnih strukturah. Raziskali smo zmagovalce in poražence $v$ tej tekmi sodelovanja $\mathrm{v}$ tranzicijskem kapitalizmu.

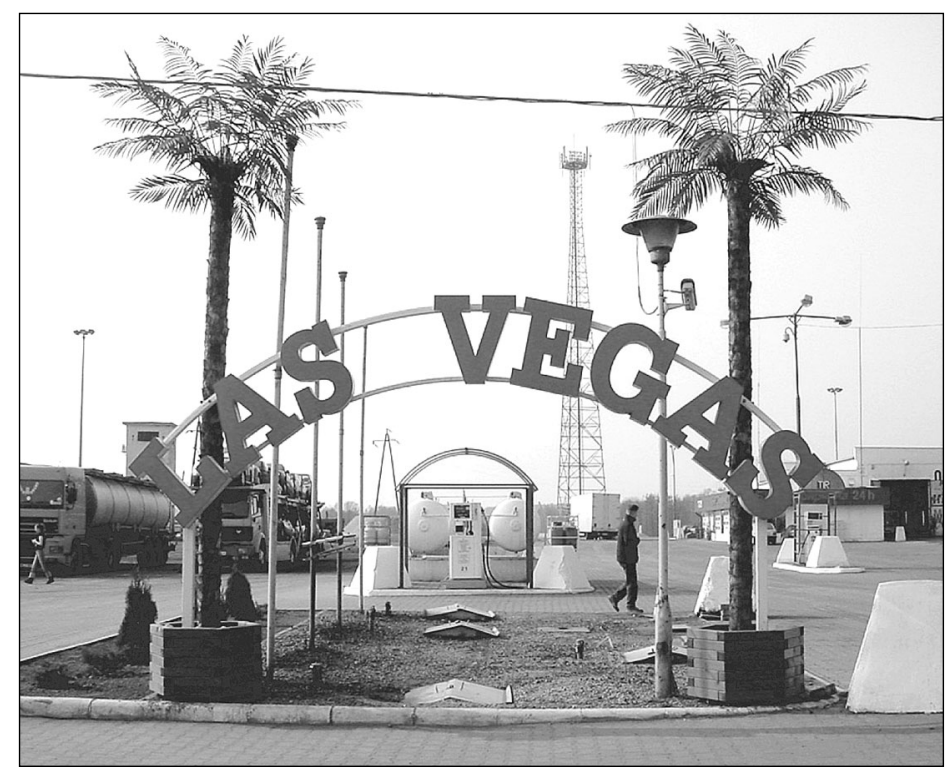

Slika 16: Reklame za servisno enoto "Las Vegas« z obeti eksotičnih doživetij. (Maximiliano Piperno)

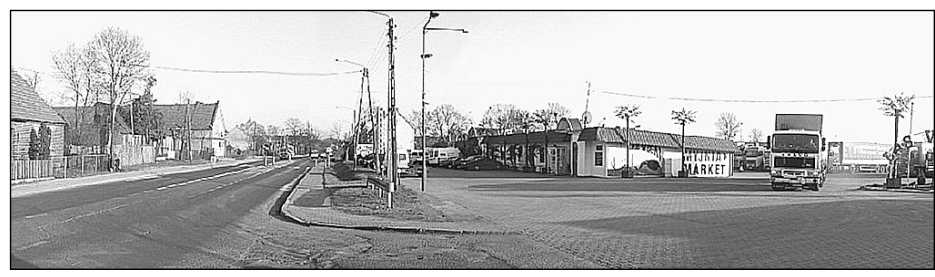

Slika 17: Servisna enota "Las Vegas « v vaškem okviru: tuja, zagrajena tipologija. (Maximiliano Piperno)

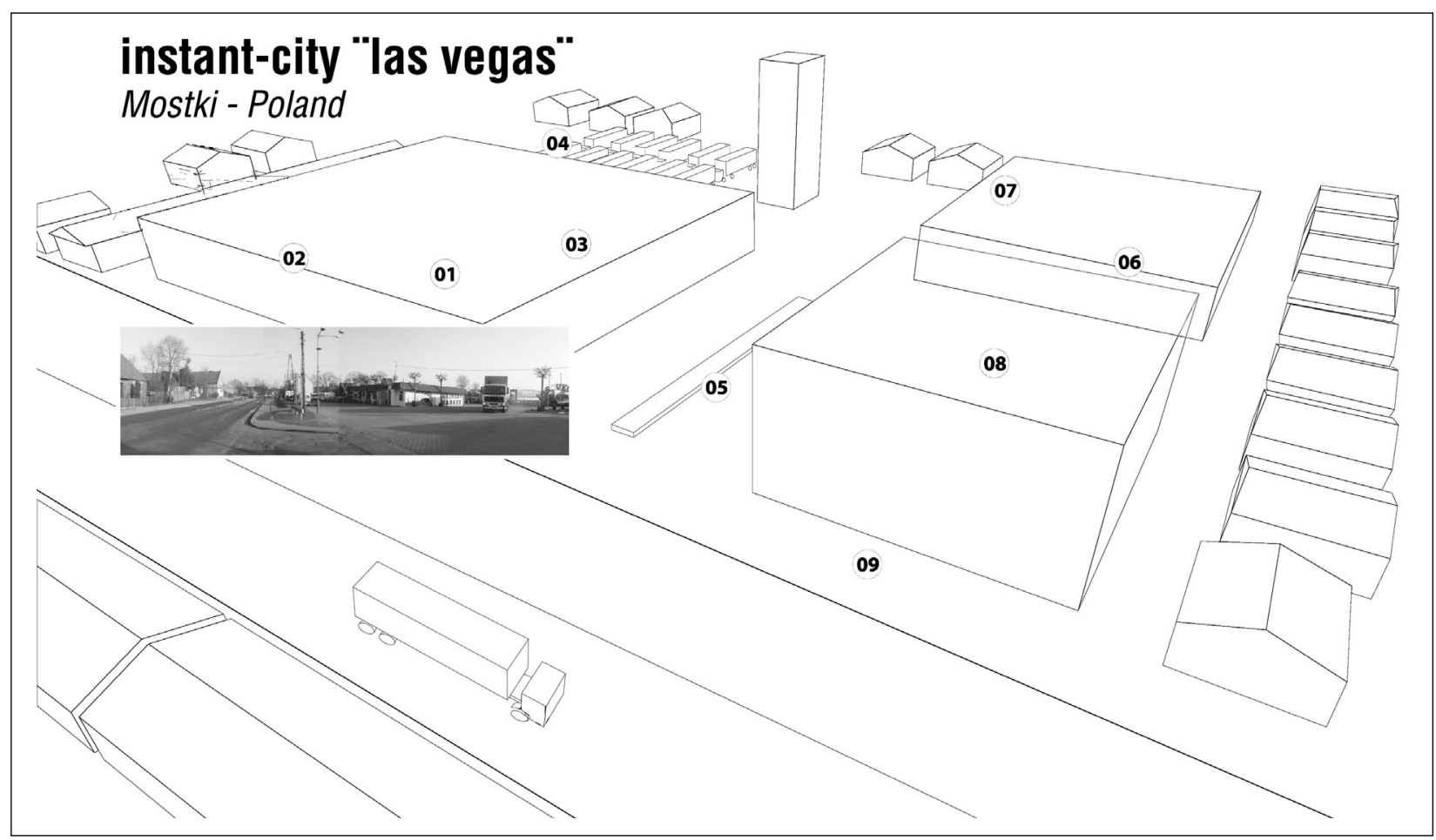

Slika 15: "Las Vegas« - primer instantnega mesta (Mostki, Poljska); 24-urni program: 01 supermarket, 02 bar-restavracija, 03 menjalnica, 04 parkirišče za tovornjake, 05 bencinska črpalka, 06 pralnica za tovornjake - garaža, 07 barklub, 08 motel, 09 parkirišče za osebna vozila. (Maximiliano Piperno) 
Povečano dejavnost ob zahodnem delu koridorja na Poljskem so sprožile nove tovarne, povečani promet dobrin v vzhodno Evropo [9], povečana količina dnevnih migrantov med Rusijo, Poljsko in zahodno Evropo ter povečanje števila neformalnih trgovcev.

V zahodni Poljski smo prepoznali tri osrednja območja proizvodnih zmogljivosti.[10] Najprej so to posebne gospodarske cone (PGC) [11], prve so ustanovili leta 1995 , a so le delno uspešne, čeprav so na petem mestu med vsemi trinajstimi lokacijami v državi. Druga oblika so tovarne, ki so se razvile iz poslovnih vezi pred letom 1991; takšna primera sta IKEA in podjetje v njeni lasti Swedwood Group, ustanovljena leta 1991 na območju Zbaszyneka in razširjena $\mathrm{z}$ novimi tovarnami leta 1999.[12] Tretja in najuspešnejša oblika proizvodnih zmogljivosti je območje Tarnowo Podgorne v bližini Poznana, kjer prebiva 14.000 ljudi. Uspelo jim je privabiti 1.800 podjetij, od katerih je 32 neposredno v koridorju Berlin-Moskva.[13] Zaradi deregulacije in podpore mestne uprave ima to območje najvišjo stopnjo gospodarske rasti na Poljskem. [14]

V raziskavi je opis razvoja storitev ob 150-kilometrski črti od nemško-poljske meje do

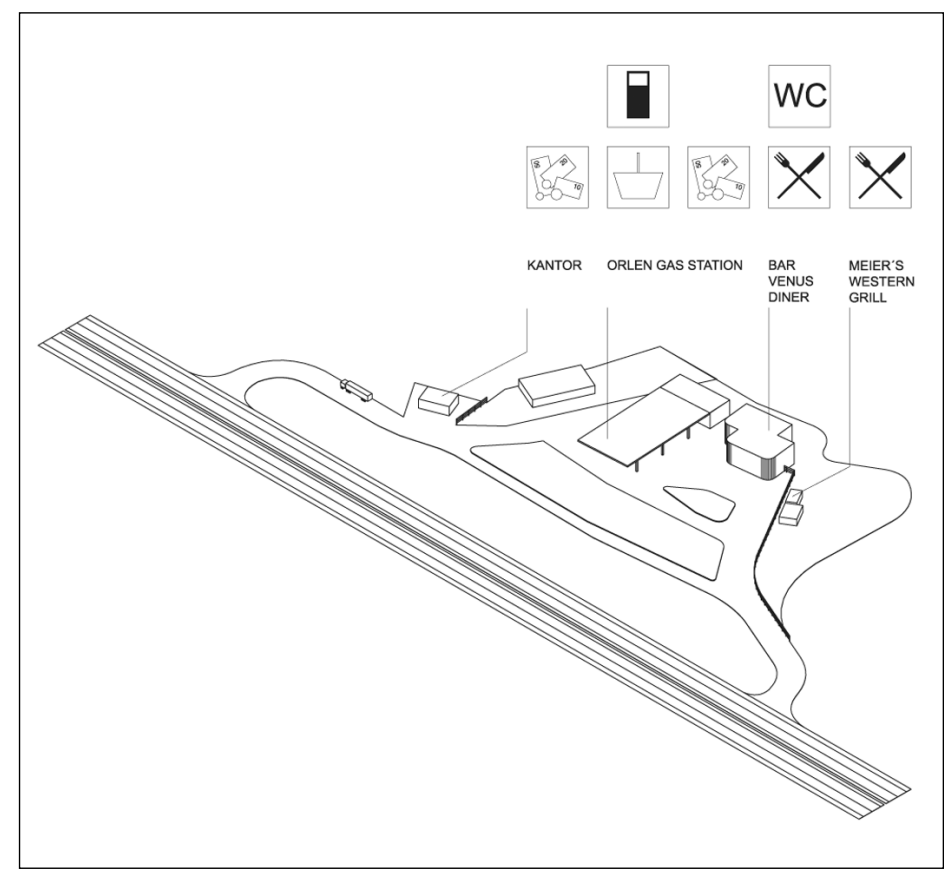

Slika 18: Inventura servisne aglomeracije z Orlenom, poljsko naftno družbo, ki je pred dvema letoma kupila bencinsko črpalko in okoli nje zgradila zid. Tako je preprečila dostop do Maier's Western Grilla, neformalnega obrata hitre prehrane, ki so ga po dveh mesecih zaprli. (Nina Gribat in Linda Hilfling) mesta Broje.[15] Iz popisa sledi, da na območju živi približno 10.000 prebivalcev in da je tam 16 bencinskih črpalk, 13 hotelov, 12 restavracij, 12 nakupovalnih središč, 11 lokalov, 10 naselij, 9 pralnic za tovornjake, 7 javnih hiš, 6 menjalnic, 6 plinskih črpalk, 5 počivališč za tovornjake, 4 avtomehanične delavnice, 2 trgovine s spominki, 2 radijski postaji in 2 javni stranišči. Če primerjamo to območje z Berlinom, tj. razmerje števila prebivalcev na dejavnost, dobimo naslednjo sliko: ena restavracija ali lokal na 700 prebivalcev v Berlinu in na 434 prebivalcev v 150kilometrskem poljskem koridorju, en hotel na 4.000 prebivalcev v Berlinu in na 770 prebivalcev v koridorju, ena črpalka na 12.600 prebivalcev $\mathrm{v}$ Berlinu in na 625 prebivalcev $\mathrm{v}$ koridorju.[16] Primerjava pokaže, kakšna je urbana gostota v koridorju na Poljskem. Če vemo, da vse te dejavnosti delajo 24 ur, postane jasno, da govorimo o metropolitanski pojavnosti.

V tej servisni aglomeraciji se pravkar odvija tretji val transformacije.

Prvi val se je začel po letu 1991, ko se je podeželska cesta spremenila v servisni niz neformalnih, individualnih servisov $\mathrm{z}$ nerazvito (izrazito) tipologijo. Drugi val se je začel približno leta $2000 \mathrm{~s}$ transformacijo v formalne, legalne in razvite servise s primerno tipologijo. Njihov uspeh pravkar sproža bolj individualizirane naložbe za sodelovanje v globalnem pretoku. Ta tretji val je globalizacija servisnega trga. Resda se je proces začel že sredi 90. let, ko so globalni igralci pokupili bencinske črpalke, vendar je zdajšnji pristop drugačen, tj. prevzem servisnih aglomeracij v celoti in njihovo preoblikovanje $\mathrm{v}$ okolja, primerna za globalno porabo. Naslednji val transformacije bo izvedba avtoceste prek Poljske v smeri zahod-vzhod. Dolžina načrtovane avtoceste je $700 \mathrm{~km}$, zaenkrat so jih zgradili manj kot 100. Čeprav EU ponuja sredstva za hitrejšo graditev, Poljska ni sposobna prispevati svojega 50-70 odstotnega nacionalnega deleža. Izvedba je torej upočasnjena, vendar verjetna. $V$ zahodnem delu koridorja prek Poljske to pomeni izrazito transformacijo. Danes je E30 podeželska, počasna cesta, ki pelje skozi vasi in naselja, kar omogoča neposredni dostop do globalnega pretoka dobrin. Avtocesta bo pospešila potovanja, povezave med večjimi mesti bodo hitrejše, vasi pa bo obšla. Edina možnost ohranitve zdajšnjih servisov v prihodnosti je izgradnja 
avtocestnega izvoza, tihi boj za dostop do te infrastrukture že poteka. Naložbe v servisne industrije se niso ustavile, nasprotno, lokalni investitorji so prepričani, bodisi da bo izvoz blizu njihovih lokacijam ali da bo za uporabo avtoceste treba plačati cestnino. Verjamejo, da bo obseg prometa na E30 še naprej primerljiv zdajšnjemu oziroma se bo gradnja avtoceste zelo zavlekla. Med raziskovanjem smo izvedeli, da so lokacije izvozov pretežno že določene, vendar sta financiranje in čas dokončanja še vedno neznanki.

\section{Primer: E30 od nemške meje do Poznana}

Raziskali smo tri tipološke primere: pojav nove tipologije v primeru Las Vegasa (Maximiliano Piperno, Nina Gribart, Linda Hilfling), prepletanje globalnih servisnih območij in lokalne vaške strukture $\mathrm{v}$ primeru Torzyma (Nina Gribart, Linda Hilfling) in transformacijo, ki jo izvajajo globalni igralci na servisnih aglomeracijah v primeru Orlena (Nina Gribart, Linda Hilfling).

Raziskava o Las Vegasu analizira novo tipologijo, ki je nastala iz 24-urne neformalne servisne aglomeracije (izvedel Maximiliano Piperno). Instantno mesto Las Vegas v zahodni Poljski je usidrano $\mathrm{v}$ sosednjo vas Mostki, vendar je od nje ločeno. Gre za enovito entiteto namenjeno ponujanju vseh potrebnih storitev tranzitnim potnikom. Štiriindvajseturni program ponuja supermarket, motel, bencinsko črpalko, pralnico za tovornjake, restavracijo, bar, menjalnico, telefon, parkirišče za tovornjake, varovano parkirišče za avtomobile in prostitucijo. Vozniki tovornjakov v povprečju na tem območju ostanejo 11 ur (75\%), vozniki avtomobilov pa uro in pol (15\%). Hkrati je na območju povprečno 60-70 tovornjakov, včasih pa le 20-30. Ruski vozniki tovornjakov so v Las Vegasu $\mathrm{v}$ ponedeljek in torek, poljski pa čez vikend. Območje zaposluje skoraj 70 ljudi iz okoliških krajev. [17] Instantno mesto deluje kot mesto v malem, v njem voznikom tovornjakov ponujajo vse storitve in programe, ki jih v vozilih ni. V kabinah tovornjakov namreč vozniki že imajo različne naprave, to so mobilne življenjske celice $\mathrm{z}$ radiom, hladilnikom, posteljo, majhno kuhi- njo, slikami družine idr., tako da s priklopom (»plug in«) v servisno postajo Las Vegasa zares postanejo mesto $\mathrm{v}$ malem.

Ta uspešna tipologija ni generična aglomeracija, oblikovali in zgradili so jo za natančno določene storitve namenjene tranzitnim potnikom. Vloga sosednje vasi je nepomembna, saj samo zagotavlja infrastrukturo in zaposlene, ni nikakršnega stika med grajenimi tkivi. Servisna postaja je pristala zraven vasi kot NLP, zdaj generira 24-urno poslovanje in skoraj urbano življenje.

Raziskava o vasici Torzym je o razvoju servisov. [18] Tam prebiva približno 1.000 ljudi, ponujajo pa naslednje tranzitne programe: pralnico za tovornjake, trgovino Korb, vulkanizerstvi Volvo in AS 24, bencinsko črpalko Shell, restavracijo, motele Pedro, Alaska,

Dear Orlen Gas Company, Berlin, May 2004

In a letter directed to you the 5th of April 2004 concerning the architectural layout of the orlen gas station at E30, we hoped to get your help in the enlightening of the story behind the wall erected between Orlen gas station, Venus Bar and the recently closed down Maier's Western Grill.

To our disappointment we still haven't received any comment from you. We assume that this must rely entirely on your company being occupied with more important matters, but we are still waiting in anticipation and hope that you'll soon get the time to return to us.

Meanwhile we have taken the opportunity to make some suggestions on how you can alter and re-design the wall. our designs vary in range an expense from big luxurious versions to simple almost no-budget solutions. However, we must underline that any of the suggestions - without regard to their actual cost - will enable you to improve upon the spatial mistakes due to the fatal design of your wall.

All suggestions have been enclosed in this letter together with a detailed budget.

We are looking very much forward to receive your comments on our Architough-solutions. Please don't hesitate to contact us with any questions related to the suggested alterations.

Yours sincerely,

Architough
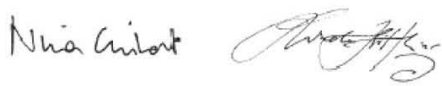

Nina Gribat

Muskauer Str. 19

Linda Hilfling

D-10997 Berlin

Enghave Plads 17, 2.tv DK-1670 Copenhagen V

Slika 19: Pismo naftni družbi Orlen s predlogi popravkov zidu. (Nina Gribat in Linda Hilfling) 
Pizzeria in Marco, nočni klub Déjà vu in hotela Zajazd Chobry in Paradise. Vsi so ob cesti E30 in le nekaj metrov od značilnega vaškega prepleta programov, tj. stanovanjskih stavb, cerkve, pošte, šole in vaškega trga. Vsa vas se je prilagodila sodelovanju v globalnem pretoku dobrin in ljudi oziroma se ne zmeni za obsežni promet, ki se vali skozi naselje. Zdi se, da so izposlovali ugodno razmerje med globalnimi in lokalnimi potrebami. V gospodarskem smislu lahko trdimo, da je tranzitna cesta močno pospešila razvoj. Posledično je vaški župan začel načrtovati različne javne programe, kot so telovadnica, bazen in drugi športni ter prostočasni programi. Prihodnost je tudi videti varna, saj je v neposredni bližini vasi načrtovan vstop na avtocesto. Raziskovalki sta izdelali razvojni scenarij, s katerim sta raziskali možnost koristne izrabe avtoceste za vas, da bi se tako

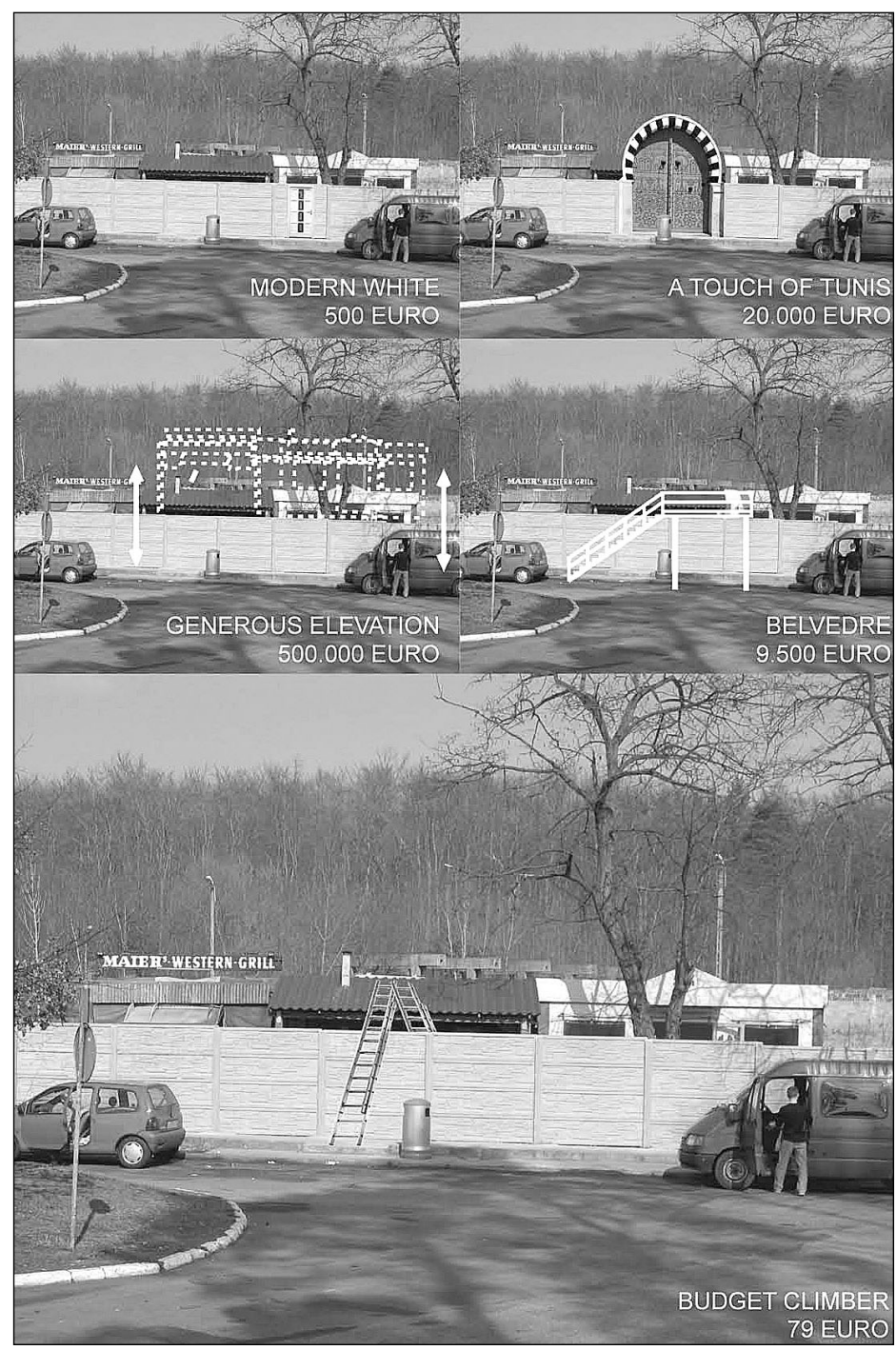

Slika 20: Scenariji popravkov zidu pred Maier's Western Grillom. (Nina Gribat in Linda Hilfling) izognili posledicam, ki jih obvoznice navadno povzročijo. Namesto upočasnitve avtoceste sta predlagali ohranitev zdajšnjih razmer in razvoj razširjene servisne postaje za avtocesto, ki vključuje programe, optimizirane na tranzitne potnike (podobno prej opisanemu Las Vegasu) in ponuja tudi vse prihodnje lokalne programe. Previdno ravnotežje programov bi lahko spodbudilo sinergične učinke, tj. dodatno ponudbo voznikom tovornjakov in poslovne priložnosti za lokalne podjetnike.

Opravili smo tudi manjšo raziskava podjetja PKN Orlen gas company. Orlen, sicer največje podjetje za trgovanje $\mathrm{z}$ naftnimi derivati na Poljskem, je postavilo bencinsko črpalko $v$ bližino meje in to je prva in zadnja poljska črpalka pred mejo. Nastala je iz značilnega neformalnega monofunkcionalnega servisa in se razvila $v$ 24-urno servisno aglomeracijo z baterijo bencinskih črpalk, barom Venus (bar/restavracija), menjalnico in obratom hitre prehrane (Maier's Western Grill). V zadnjem času so se v podjetju Orlen odločili kar odločno pospraviti okolico, tako da na njihovo blagovno znamko ne bi vplival (ali jo celo okužil) precej improviziran slog neformalnih servisov v sosedstvu. Zgradili so zid, ki preprečuje pogled na menjalnico in obrat hitre prehrane. Slednjega so tako učinkovito obzidali, da so njegovi uporabniki ostali zunaj; promet se jim je zato zmanjšal s 1.000 ljudi na dan na 100 na mesec! Kmalu so ga zaprli. Gre za dokumentiran globalni učinek v izrazito lokalnih okoliščinah. Raziskovalki sta se obrnili na Orlen, izrazili svoj dvom o oblikovanju in predlagali minimalen poseg v zid. Dopisovanje sicer ni vplivalo na usodo obrata, ostal je zaprt, Orlen pa se ni odzval. Ta primer je povsem preprosto pokazal, kako v koridorju deluje tretji val razvoja; nov razvoj ne nosi nujno posledičnih koristi lokalnemu gospodarstvu.

\section{Sklepi vzdolž koridorja}

Razmere ob tranzitnem koridorju med Berlinom in Moskvo so zelo različne: v Nemčiji je infrastruktura odlična, gospodarski razvoj je ničen, na Poljskem je infrastruktura zelo slaba, gospodarstvo cveti, v Belorusiji je infrastruktura dobra, gospodarstva pa je komaj kaj, v Rusiji je infrastruktura osnovna, 
gospodarstva pa malo. Takšne razmere niso odvisne od infrastrukture, kakor bi marsikateri planer mislil, temveč od političnih in globalnih gospodarskih dejavnikov. Državne naložbe so na primer v Nemčiji pretežno usmerjene $v$ razvoj infrastrukture, na Poljskem pa spodbujata gospodarstvo predvsem bližina EU in deregulacija. V Belorusiji je, predvsem zaradi politične izločenosti, gospodarski razvoj upočasnjen, čeprav je infrastruktura dobra. Vsekakor ne razpravljamo o relevantnosti infrastrukture, toda da bi bila infrastruktura učinkovita, je treba izpolniti neki osnovni pogoj. Poljska pogosto izgublja v globalni tekmi za tovarne, npr. Hyundai Motor Group se je odločil marca 2004 svojo postaviti na Slovaškem, tudi zaradi boljše infrastrukture. Po hitri rasti zahodnih predelov je Poljska dosegla točko, ko lahko razvoj pospeši le $z$ razvojem infrastrukture. V Nemčiji bi tako morale naložbe pospeševati in omogočati lokalni razvoj v povezavi z deregulacijo, tako da bi odkrili potenciale in posledično okrepili rast $\mathrm{z}$ razvojem infrastrukture.

Prihodnja perspektiva držav ob koridorju lahko vključuje premik. Rast življenjskega standarda na Poljskem in rast proizvodnih standardov, ki ju zahteva EU, bosta povečali stroške dela. Načrtovana avtocesta na Poljskem bo približala Belorusijo evropskim trgom. Lahko predvidevamo, da bodo nižji stroški dela in proizvodnih standardov v prosti gospodarski coni v okolici Bresta tja privabili posle, seveda če bodo stabilne politične razmere lahko zagotovile varnost naložb.

$\mathrm{Na}$ lokalni ravni lahko razvoj vključuje gradnjo avtocestnih obvoznic mimo vasi. Prednostno sodelovanje v globalnem pretoku lahko hkrati pomeni razpad zaposlitvenih možnosti ob koridorju, tako da bodo vasi postale predmestja Berlina, Poznana in Varšave. Vprašanje za planerje je, kako uveljaviti globalno hitrost ob koridorju, da bodo lahko sodelovala tudi lokalna gospodarstva. Treba bo razviti nove servisne tipologije, ki izhajajo iz tekoče evolucije, vendar razširjene $z$ možnostmi integracije globalnih standardov in potreb.

Wilfried Hackenbroich, M. Arch. (ZDA), dipl. ing. arhitekt, svetovalec Bauhaus Kolleg (Event City, Serve City, Transit Space, Transnational Space)

v Fundaciji Bauhaus Dessau, Nemčija

E-pošta: info@hackenbroich.com

\section{Opombe}

[1] Multiplicity (2003), The doubling of the highway, Intervju s Hansom Jörgom Klofatom USE, Uncertain States of Europe, Skira Editore S.p.A., Italija 2003, str. 114-117.

[2] Raziskala Diane Pfeifer.

[3] Helmut Dietrich (2003) The new border regime at Bug River FFM, Statewatch bulletin Vol. 13, januar-februar 2003

[4] INTERREG iniciativa: podpora čezmejnega in transnacionalnega sodelovanja med državami članicami in sosednjimi državami; sredstva so namenjena samo članicam EU.

[5] PHARE CBC: podpora in financiranje čezmejnega sodelovanja med članicami EU in državami kandidatkami.

[6] Tacis CBC: podpora in financiranje prek-mejnega sodelovanja med zahodnimi obmejnimi regijami Rusije, Belorusije, Ukrajine in Moldavije z državami članicami EU; sorodne povezave z EU: http://www.europa.eu.int/comm/world/enp/ document_en.htm http://www.europa.eu.int/comm/enlargement/ index_en.html http://www.europa.eu.int/comm/ external_relations/index.htm

[7] Alexander Sergej, podžupan mesta Brest, med pogovorom v Brestu, oktober 2003.

[8] Širša Evropa: Naloga krepitve čezmejnega sodelovanja z novimi sosedami, tiskovno gradivo EU, DN:IP/03/922, z dne 01/07/2003, Bruselj, julij 2003, http://europa.eu.int/comm/enlargement/docs/ news.htm

[9] Zaradi zahtevnejših carinskih postopkov v Belorusiji prevozniki čedalje več uporabljajo severno smer do Moskve prek Litve in Latvije.

[10] Raziskal Martin Cagno.

[11] Posebne gospodarske cone: Kostrzyn, od 1996, 246 ha, 23 podjetij; Gorzow WIkp, od 2001, 62 ha 2 podjetji; Slubice, od 1996, 101 ha, 23 podjetij; Nowa So, od 2001, 48 ha, 1 podjetje. Vir: Bartosz Begej, marketinški menedžer SEZ, Kostrzyn - Slubice, $v$ intervjuju marca 2004 (vprašanja: Martin Cagno in Wilfried Hackenbroich).

[12] Robert Gdula, menedžer za proizvodnjo, The Swedwood Groupe, območje Zbaszynek, intervju marca 2004 (vprašanja: Martin Cagno).

[13] Štirinajst iz Nemčije, 7 iz Poljske in 11 iz drugih zahodnoevropskih držav.

[14] Waldy Dzikowski, okrožni administrator, Tarnowo Podgorne, intervju v marcu 2004 (vprašanja: Martin Cagno)

[15] Raziskali Nina Gribat in Linda Hilfing.

[16] Raziskava količin in lokacij za Berlin: http: //www. berlin.de/branchenbuch/_bin/index.php Berlin ima 3.4 milijone prebivalcev, 270 bencinskih črpalk, 4860 restavracij in lokalov, 840 hotelov in nastanitev.

[17] Menedžer Las Vegasa, intervju marca 2004 (vprašanja: Maximiliano Piperno)

[18] Raziskali Nina Gribat in Linda Hilfling.

\section{Medmrežne strani:}

www.bauhaus-dessau.de www.transitraeume.de

www.transnational-spaces.de

www.hackenbroich.com 